\title{
Utilization of untreated and formaldhyde treated skimmilk powder and skimmilk powder-barley pellets by ruminants
}

\author{
Liisa Syrjälä ${ }^{1}$ ), Eeva-Lissa Syväoja ${ }^{2}$ ) and Marjatta Boman ${ }^{1}$ ) \\ 1) Department of Animal Husbandry, University of Helsinki, 00710 Helsinki 71 \\ 2) Biochemical Research Institute, Kalevankatu-56 B, 00180 Helsinki 18
}

\begin{abstract}
The utilization of spray-dried fat free milk powder in three different froms 1) untreated, 2) treated with formaldehyde $(0.4 \mathrm{~g}$ formaldehyde $/ 100 \mathrm{~g}$ crude protein) and 3) pelleted with barley meal (30\% milk powder and $70 \%$ barley meal) was studied with three rumen-fistulated dairy cows according to a $3 \times 3$ Latin square. The effects of different treatments were investigated with respect to rumen fermentation, microbial determinations and milk and blood analyses.

The basic feed in every diet consisted of hay, grass silage, barley, oats, mineral and vitamin mixtures. Feeding was according to nutrient requirement. In each diet $25 \%$ of the DCP required for milk production was replaced with milk protein.

The $\mathrm{NH}_{3}$ concentration in the rumen fluid was lowest on the pelleted diet followed by the formaldehyde treated and untreated skimmilk powder diets, the differences only being significant between the pelleted and untreated diets. The $\mathrm{pH}$ values were significantly higher on the pelleted diet than on the other diets. The VFA content of the rumen fluid was similar on the different diets.

The total amount of rumen ciliates was highest on the untreated skimmilk powder diet and lowest on the pelleted diet. The quantity of bacteria was however lower on the untreated skimmilk powder diet than on the other diets. Bacteria constituted $72-88 \%$ of the total microbe mass on the different diets. The total microbe mass consisted of the following percentages of rumen content on the different diets: untreated $3.3 \%$, formaldehyde treated $3.2 \%$ and pelleted diet $2.9 \%$.

No effects on the milk yields and blood contents were found with the difterent treatments of skimmilk powder. Milk protein- $\%$ was significantly higher on the untreated skimmlik powder diet than on the pelleted diet.
\end{abstract}

Utilization of dietary protein by ruminants depends to a great degree on its solubility. The more soluble proteins produce more ammonia in the rumen and are not utilized so well by ruminants (McDonald 1952, Chalmers and Synge, 1954). Many experiments, as reviewed by Chalupa (1975), Ferguson (1975) and BARRY (1976) have shown, that certain processing of dietary protein, for example heating and formaldehyde treatment, can promote increased nitrogen utilization by reducing the rate of the degradation of the proteins and thus the ammonia production in the rumen. 
Casein has a very high solubility. The percentage of the dietary protein escaping fermentation in the rumen is only $9 \%$ for casein, whereas it is $61 \%$ for soya bean meal and $71 \%$ for fish meal (HumE 1974). The utilization of this high quality milk protein is thus rather low, but can be improved by rumen by-pass (Chalmers et al. 1954, Faichney and Weston 1971, Asplund 1975).

In milk powder preparation different treatments are used including drying at various temperatures. How these treatments influence the solubility, and thus the utilization by ruminants, is not well investigated. The purpose of this experiment was to study, mainly with rumen fermentation and microbial determinations, the utilization by dairy cows of spray-dried fat free milk powder, in the following 3 forms: untreated, treated with formaldehyde, and pelleted with barley meal. These physiological investigations belong to a larger experimental program concerning in vitro (SYVÄOJA and KREULA 1978) and milk production experiments (SYRJÄLÄ et al. 1978) with skimmilk powder. This program was begun because the over-production and marketing difficulties led, in 1976, to the use of skimmilk powder in feed mixtures for dairy cows in Finland.

\section{Experimental procedures}

\section{Experimental feeds and feeding}

The experiment was performed with three rumen-fistulated dairy cows according to a $3 \times 3$ Latin square. Every experimental period lasted two weeks. The milk powder used in the experiment was spray-dried fat free milk powder, treated as follows:

1) Untreated milk powder

2) Formaldehyde treated milk powder $(0.4 \mathrm{~g}$ formaldehyde $/ 100 \mathrm{~g}$ crude protein)

3) Pelleted feed (30\% milk powder and $70 \%$ barley meal)

The basic feed in every diet consisted of hay, grass silage, barley and oats preserved with propionic acid (Table 1), and mineral and vitamin micxtures. The feeding was after nutrient requirement. In each diet $25 \%$ of the digestible crude protein needed for milk production was replaced with milk protein (Table 2).

At the beginning of the experiment the average time after calving was 36 days and at the end 78 days. Feeding and milking was performed twice a day. Milk produced was weighed at every milking. The animals were weighed at the beginning of every experimental period.

\section{Sampling and analyses}

The feed rations were weighed at every feeding time, these amounts being adjusted for energy and protein requirements every week. Food refusals were weighed once a day. The sampling and analysing of feeds were performed as described by SYrJÄLÄ et al. (1978). 
Table 1. The mean chemical compositions of the feeds.

\begin{tabular}{|c|c|c|c|c|c|c|c|}
\hline & Hay & $\begin{array}{l}\text { Grass } \\
\text { silage }\end{array}$ & Barley & Oats & $\begin{array}{c}\text { Untreated } \\
\text { milk } \\
\text { powder }\end{array}$ & $\begin{array}{c}\text { Formaldehyde } \\
\text { treated milk } \\
\text { powder }\end{array}$ & Pellet \\
\hline Dry matter ................. & 82.8 & 26.9 & 75.8 & 74.2 & 96.2 & 95.9 & 90.2 \\
\hline$\%$ of dry matter: & 7.1 & 9.6 & 2.4 & 2.8 & 7.9 & 8.5 & 6.4 \\
\hline Organic matter .... & 92.9 & 90.4 & 97.6 & 97.2 & 92.1 & 91.5 & 93.6 \\
\hline Crude protein ....... & 13.0 & 15.4 & 13.7 & 13.7 & 36.2 & 35.8 & 19.8 \\
\hline True protein ......... & 9.8 & 8.3 & 8.2 & 12.0 & 36.2 & 35.8 & 19.0 \\
\hline Crude fat ............. & 2.4 & 5.7 & 2.1 & 5.8 & 0.1 & 0.1 & 1.8 \\
\hline Crude fibre ........... & 31.7 & 24.4 & 5.2 & 11.8 & - & - & 4.7 \\
\hline $\mathrm{N}$-free extract $\ldots \ldots$. & 45.8 & 44.9 & 76.6 & 65.9 & 55.8 & 55.6 & 67.3 \\
\hline Sugars ................. & 6.3 & 6.3 & 5.4 & 4.0 & 52.0 & 52.0 & 19.4 \\
\hline
\end{tabular}

Table 2. Average intake of different feeds, kg/day.

\begin{tabular}{|c|c|c|c|}
\hline & $\begin{array}{c}\text { Untreated } \\
\text { diet }\end{array}$ & $\begin{array}{c}\text { Formaldehyde } \\
\text { treated diet }\end{array}$ & $\begin{array}{l}\text { Pelet } \\
\text { diet }\end{array}$ \\
\hline Hay ...................... & 2.6 & 2.5 & 2.2 \\
\hline 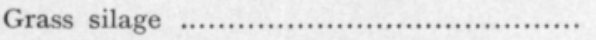 & 14.3 & 14.4 & 14.2 \\
\hline Barley-oats mixture $(50: 50) \ldots \ldots \ldots \ldots \ldots \ldots . . . . . .$. & 8.9 & 8.2 & 5.0 \\
\hline 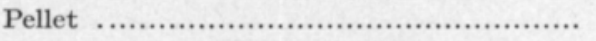 & - & - & 2.6 \\
\hline Untreated milk powder ......................... & 0.9 & - & - \\
\hline Formaldehyde treated milk powder .......... & - & 0.9 & - \\
\hline
\end{tabular}

The rumen samples were taken six times on each of the last two day sof every experimental period:

1) In the morning before feeding, at 4.45 a.m.

2) 1 hour after the beginning of feeding, at 6 a.m.

3) 2 hours " " at 7 a.m.

4) 4 hours " " at 9 a.m.

5) 6 hours " $"$ at 11 a.m.

6) 8 hours " " at 1 p.m.

The $\mathrm{pH}$ and ammonia levels were determined immediately for each rumen sample, $\mathrm{pH}$ with A Beckman meter Model 76 and ammonia nitrogen colorimetrically after centrifuging ( $10 \mathrm{~min}$ at 2000 r.p.m.) according to a modification of the method of McCullough (1967). The determinations of volatile fatty acids (VFA) were done on all the samples taken six times a day by gas chromatography (CotTyN and BoucQue 1968).

The rumen bacteria and ciliates present were determined for the samples taken at $4.45,7.00$ and 11.00 a.m. once during every experimental period. The total numbers and identification of the ciliates were determined as described by SYRJÄLÄ et al. (1976). The bacterial cells were counted using a counting 
chamber with $1 \times 1 \mathrm{~mm}^{2}$ and $0.2 \mathrm{~mm}$ depth. Only total numbers were counted for the bacteria. Three preparations were made of each rumen sample for the counts.

The cell volumes for ciliate species were collected from the relevant literature (ref. SYRJÄLÄ et al. 1976) or calculated according to the method introduced by Schumacher (1962). For the bacterial cells the mean volume of $1 \mu^{3}$ was used (WARNER 1962).

The milk and blood samples were taken and analysed as described by SYRJÄLÄ et al. (1978).

\section{Results and discussion}

\section{Rumen fermentation}

The $\mathrm{pH}$ values of the rumen fluid kept within the normal ranges on all the diets, the limits being 6.14 and 6.75 (Table 3, Figure 1). There were no significant differences $(\mathrm{P}>0.05)$ between the diets containing untreated or formaldehyde treated milk protein. The $\mathrm{pH}$ values on the pellet diet, however, were higher than on the other diets especially in the samples taken soon after feeding $(\mathrm{P}<0.01$ or $\mathrm{P}<0.05)$.

The highest levels for the rumen fluid ammonia concentration were achieved after two hours from feeding (Table 3, Figure 1). The highest value, $18.5 \mathrm{mg}$ $\mathrm{NH}_{3}-\mathrm{N} / 100 \mathrm{ml}$, was on the diet containing untreated milk powder and the lowest, $15.3 \mathrm{mg} \mathrm{NH}_{3}-\mathrm{N} / 100 \mathrm{ml}$, on the pellet diet, the differences being significant $(\mathrm{P}<0.01)$. The highest level of ammonia concentration reached on the formaldehyde diet was between these values and did not differ significantly from them $(\mathrm{P}>0.05)$. Following six hours from the beginning of feeding the ammonia concentrations of the rumen fluid returned, on all diets, to before feeding levels.

The total amount of volatile fatty acids varied, on the different diets and sampling times, between $7.0-11.1 \mathrm{mmol} / 100 \mathrm{ml}$ rumen fluid (Table 3, Figure 1).

Table 3. $\mathrm{pH}$, ammonia and volatile fat acids in the rumen fluid on different diets. The values are the averages of different sampling times.

\begin{tabular}{|c|c|c|c|}
\hline & $\begin{array}{c}\text { Untreated } \\
\text { diet }\end{array}$ & $\begin{array}{c}\text { Formaldehyde } \\
\text { treated diet }\end{array}$ & $\begin{array}{c}\text { Pellet } \\
\text { diet }\end{array}$ \\
\hline $\mathrm{pH}$ & 6.31 & 6.37 & 6.50 \\
\hline 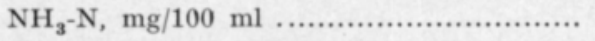 & 10.6 & 10.4 & 9.6 \\
\hline Total VFA, mmoles $/ 100 \mathrm{ml}$................... & 9.65 & 9.07 & 8.46 \\
\hline Acetic acid, molar $\%$................... & 64.3 & 64.2 & 65.9 \\
\hline $\quad$...................... & 19.7 & 20.0 & 19.3 \\
\hline ......................... & 13.1 & 13.0 & 11.8 \\
\hline Isovaleric adid , & 1.5 & 1.5 & 1.7 \\
\hline $\quad$ (n.................... & 1.4 & 1.3 & 1.3 \\
\hline Ratio acetic: propionic ........................ & 3.3 & 3.2 & 3.4 \\
\hline , acetic: butyric .......................... & 4.9 & 4.9 & 5.6 \\
\hline propionic: butyric ....................... & 1.5 & 1.5 & 1.6 \\
\hline
\end{tabular}



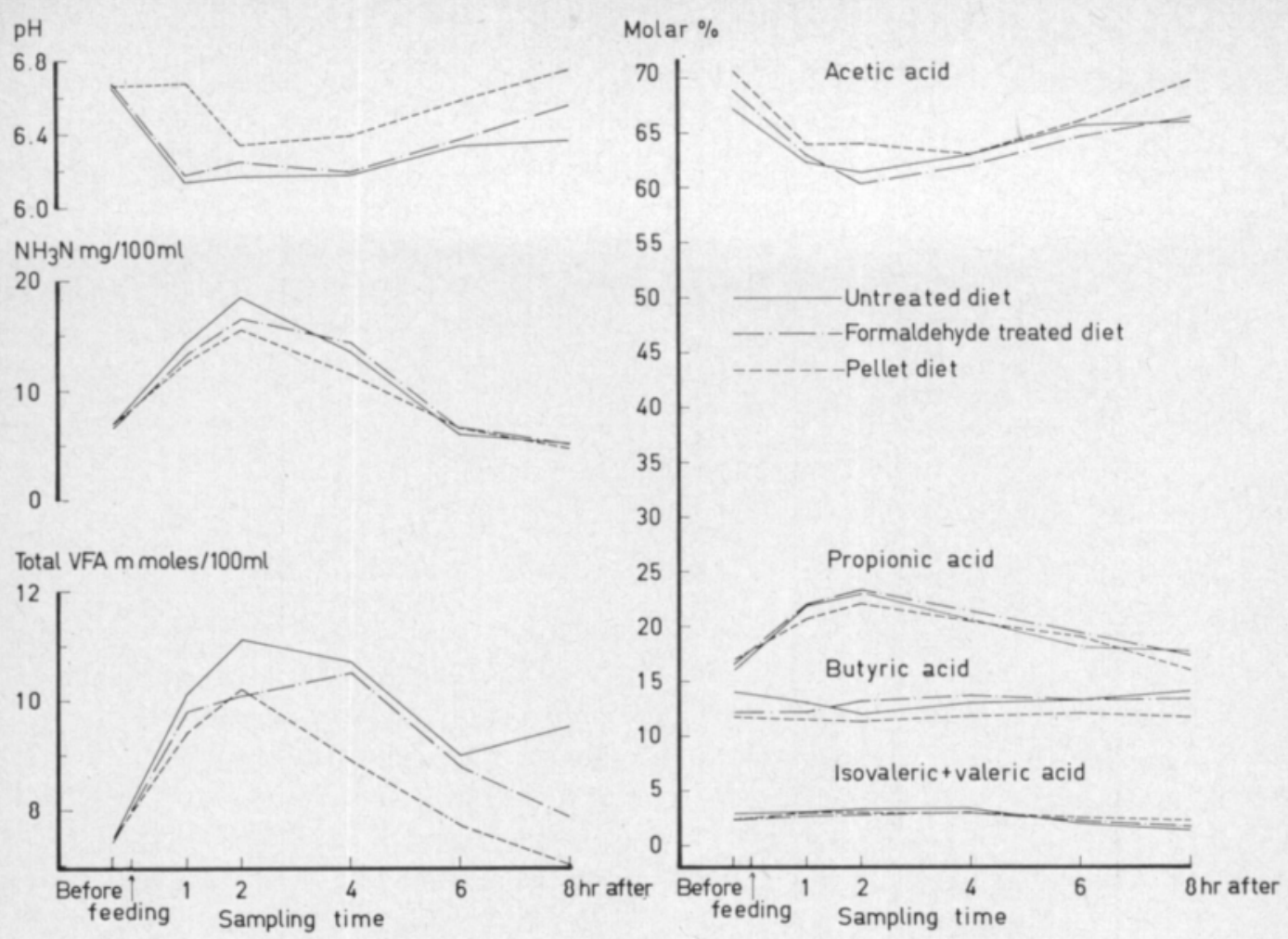

Fig. 1. $\mathrm{pH}, \mathrm{NH}_{3}-\mathrm{N}$ and VFA in the rumen fluid of cows on different diets.

The differences between the different diets were not significant $(\mathrm{P}>0.05)$, although on the diet containing untreated milk powder they were, at all the sampling times, a little higher than on the other diets. No significant differences, between diets, were found in the molar proportions of the different acids apart from butyric acid, the value of which, on the pellet diet sample taken at one p.m., was significantly lower $(\mathrm{P}<0.01)$ than in the corresponding samples on the untreated and formaldehyde treated milk protein containing diets.

The formaldehyde applications, $0.4 \%$ of crude protein, used in this experiment seems to be rather low for the protection of the milk powder protein, as no significant differences in the rumen fermentation results between untreated and formaldehyde treated milk protein containing diets were found. The same formaldehyde treatment somewhat decreased, in in vitro experiments, the solubility of milk protein (SYvÄOJA and KREULA 1978).

A summary of the results from the literature (BARRY 1976, HAGEMEISTER 1977), regardless of the type of protein, show a tendency wherein formaldehyde application rates of under $0.3 \%$ of treated crude protein gave practically no response. Application rates between 0.3 and $1.2 \%$ produced positive effects and levels higher than $1.2 \%$ had negative results.

The pelleting of milk powder and heating used in that process could be one reason fore the slowed rumen fermentation, especially for the ammonia release obtained on the pellet diet when compared with the other diets. Many experiments have shown that the heating of protein decreases ammonia formation in the rumen (Chalmers et al. 1954, Sherrod and Tillman 1962, Little 
et al. 1963, Glimp et al. 1967, Hudson et al. 1970). How important a factor the temperature used in spray-dried milk powder preparation is in the protection of protein is difficult to say. The results concerning rumen fermentation showed that it could have at least some effect. That an increase in drying temperature decreased the solubility of milk protein, was found by in vitro investigations (SYväOJA and KREULA 1978).

The lactose of milk powder could also have some effect on the rather low rumen ammonia concentrations. Readily fermentable carbohydrates have been found to depress ammonia in the rumen (McDonald 1948, 1952, BarnetT and REID 1961), particularly with rations containing large amounts of soluble nitrogen (SYRJÄLÄ 1972, 1977).

\section{Composition and volume of the rumen microbiota}

The ciliates found in the rumen fluid of the experimental animals represented 21 different species (Table 4). All species were not found in every sample. The genus Entodinium formed the largest numbers on all the diets (Figure 2), but the genus Diplodinium had the largest total volume (Figure 3).

Table 4. The mean number of cil'ate $\left(\mathrm{n} \times 10^{3}\right)$ and bacteria $\left(\mathrm{n} \times 10^{9}\right)$ cells per ml rumen content on different diets.

\begin{tabular}{|c|c|c|c|}
\hline & $\begin{array}{l}\text { Untreated } \\
\text { diet }\end{array}$ & $\begin{array}{l}\text { Formaldehyde } \\
\text { treated diet }\end{array}$ & $\begin{array}{l}\text { Pellet } \\
\text { diet }\end{array}$ \\
\hline Total ciliates .................... & $1723^{a}$ & $1203^{\mathrm{ab}}$ & $767^{b}$ \\
\hline Holotrichs . ......................................... & 56 & 64 & 32 \\
\hline Isotricha prostoma .......................... & 16 & 15 & 5 \\
\hline I. intestınalis ............................... & $\mathrm{C}$ & 0.4 & 0 \\
\hline Dasytricha ruminantium .................... & $28 \mathrm{ab}$ & $32^{\mathrm{a}}$ & $11^{\mathrm{b}}$ \\
\hline Charon ....................... & 12 & 17 & 16 \\
\hline Entodiniomorphs ............................... & 1667 & 1139 & 735 \\
\hline Entodinium dubardi ........................ & $453^{\mathrm{a}}$ & $349 \mathrm{ab}$ & $210^{b}$ \\
\hline E. nanellum ................................. & 192 & 120 & 100 \\
\hline E. caudatum ............................... & 77 & 54 & 22 \\
\hline E. loboso-spinosum ......................... & 5 & 9 & 5 \\
\hline 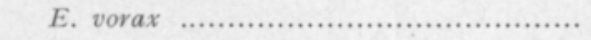 & 37 & 21 & 12 \\
\hline E. longinucleatum ........................... & 11 & 9 & 5 \\
\hline E. dilobum ................................. & 66 & 47 & 31 \\
\hline 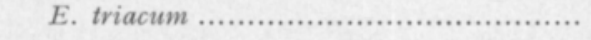 & 1 & 1 & 0 \\
\hline E. rostratum ................................. & 65 & 50 & 43 \\
\hline E. ovoideum ................................. & $141^{\mathrm{a}}$ & $83^{\mathrm{ab}}$ & $55^{b}$ \\
\hline Diplodiunium dentatum .................... & 74 & 39 & 46 \\
\hline D. posterovesiculatum ......................... & 16 & 20 & 10 \\
\hline Eudiplodinium maggii ....................... & $45^{\mathrm{a}}$ & $27 \mathrm{ab}$ & $12^{b}$ \\
\hline 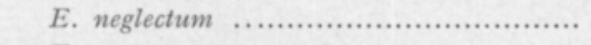 & $250^{\mathrm{a}}$ & $120^{\mathrm{ab}}$ & $109^{b}$ \\
\hline E. rostratum ................................. & $109^{\mathrm{a}}$ & $39 \mathrm{ab}$ & $34^{b}$ \\
\hline Ostracosinium obtusum ..................... & 15 & 17 & 11 \\
\hline Epidinium caudatum ......................... & 110 & 134 & 30 \\
\hline Bateria ................................................ & 24 & 26 & 26 \\
\hline
\end{tabular}

Different index letter: $\mathrm{P}<0.05$ 


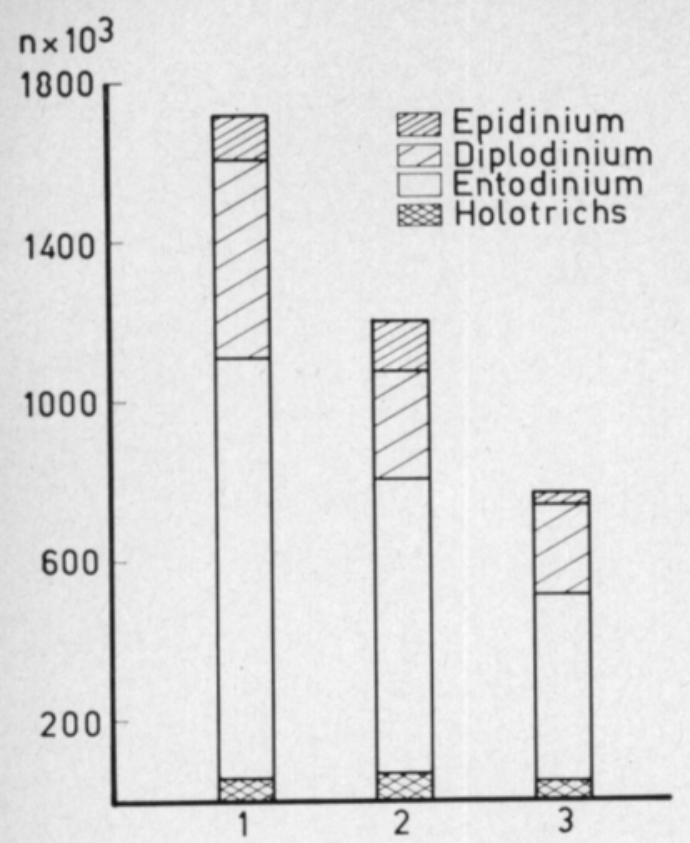

Fig. 2. The mean number of ciliate cells $\left(\mathrm{n} \times 10^{3}\right)$ per $\mathrm{ml}$ of rumen content of cows on different diets.

$1=$ Untreated diet

$2=$ Formaldehyde treated diet

$3=$ Pellet diet

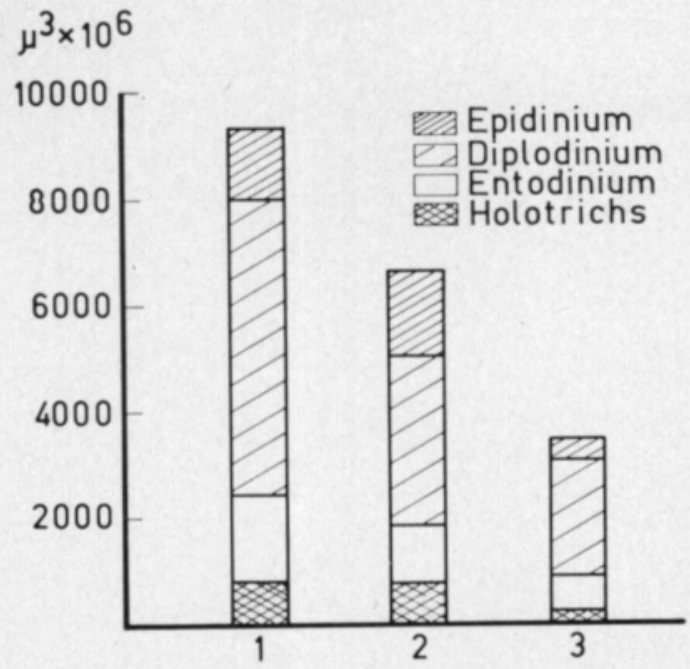

Fig. 3. The mean volume of ciliates $\left(\mu^{3} \times 10^{6}\right)$ per $\mathrm{ml}$ of rumen content of cows on different diets.

$1=$ Untreated diet

$2=$ Formaldehyde treated diet

$3=$ Pellet diet

The highest total number of ciliates was found with the animals on the untreated milk protein diet and the lowest number with animals having the pellet diet, the differences between these diets being significant $(\mathrm{P}<0.05)$. The numbers of bacteria on the different diets did not, however differ significanty $(\mathrm{P}>0.05)$.

The ciliate fauna comprised of more different species than on the silage based diets with sheep (SYRJÄLÄ et al. 1976) when, for instance, the holotrichs ciliates were completely absent. The holotrichs require soluble sugars as a source of energy (Hungate 1966). In this experiment the animals received sugars both with milk powder and forages, on average a combined weight of $1165 \mathrm{~g} /$ day, on the different diets.

The contribution of bacteria to the total microbe volume on the different diets was on averege $80 \%$ and that of ciliates $20 \%$ (Figure 4 ). The pellet diet tended to increase the proportion of bacteria, wheras with the diet containing untreated milk powder the proportion bacteria of the microbe mass was a little lower and that of ciliates respectively higher than on the other diets. The contribution of bacteria and ciliates to the total microbe mass, was however, in this experiment, about the same as in former experiments (OXFORD 1964, WARNER 1965, SYRJ ÄLÄ et al. 1976), although in some experiments the ciliate mass has been found roughly equal to that of bacteria in domestic ruminants (AвоU AKKadA 1965) and 4.6 times as high as in semi-domestic reindeer (SYRJÄLÄ et al. 1973). 


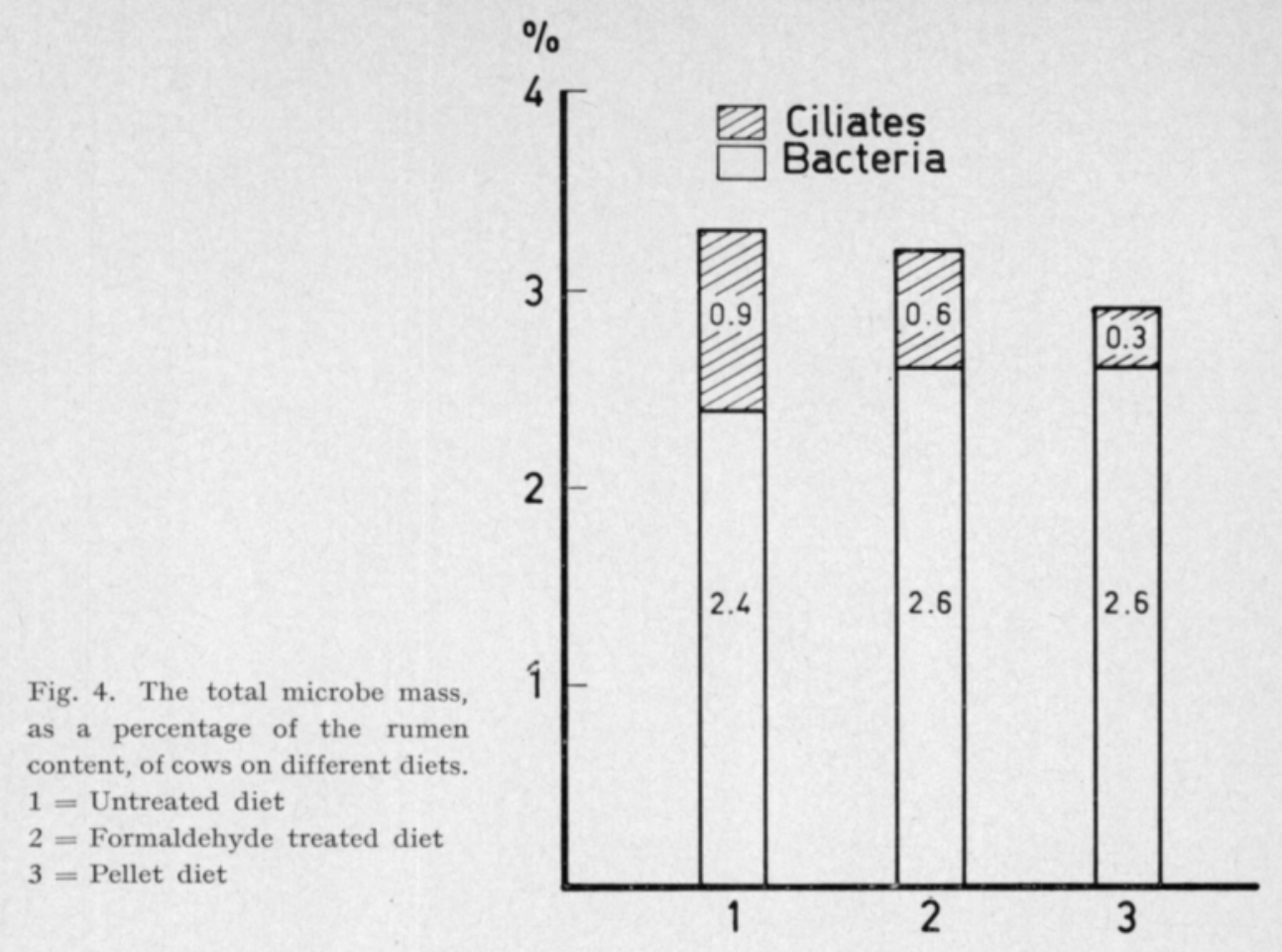

The total volume of microbe mass of the rumen content was, on the pellet diet, lower than on the untreated and formaldehyde treated milk protein containing diets, the percentages being $2.9,3.3$ and 3.2 respectively. These values were somewhat lower than those obtained in grass silage and different carborhydrate diets containing experiment with sheep, where they were between 3.5-5.2 (SYRJÄLÄ et al. 1976).

\section{Milk yield and composition of milk}

There were no significant differences $(\mathrm{P}>0.05)$ in the milk yields on the different diets, although on the pellet diet it was somewhat lower than on the others (Table 5). Also, the fat and protein contents of milk were lower on the pellet diet, the differences only being significant $(\mathrm{P}<0.05)$ in the case of the protein content between the pellet diet and untreated milk protein centaining diet. The effects of untreated and formaldehyde treated milk protein on the milk yield and the composition of milk did not differ from each other or those of the experiment with high producing dairy cows (SYRJÄL Ä et al. 1978).

Table 5. Milk yield and composition.

\begin{tabular}{|c|c|c|c|}
\hline & $\begin{array}{l}\text { Untreated } \\
\text { diet }\end{array}$ & $\begin{array}{c}\text { Formaldehyde } \\
\text { treated diet }\end{array}$ & $\begin{array}{l}\text { Pellet } \\
\text { diet }\end{array}$ \\
\hline Fat corrected milk, kg/day .................... & 19.2 & 19.7 & 18.8 \\
\hline 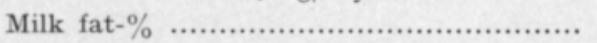 & 5.30 & 5.29 & 4.99 \\
\hline , protein-\% ................................... & 3.41 & 3.17 & 3.06 \\
\hline , lactose- $\%$................................... & 4.73 & 4.85 & 4.78 \\
\hline
\end{tabular}




\section{Composition of blood}

There were no significant differences $(\mathrm{P}>0.05)$ between the different diets in the concentrations of the blood constituents determined. All values fall within the normal ranges (RAUEN 1964). The results agree with those of the other milk powder experiment with dairy cows (SYRJÄLÄ et al. 1978).

Acknowledgements. - We wish to express our best thanks to the staff of the Valio, Farmos and Vaasan Höyrymylly companies and the Department of Animal Husbandry University of Helsinki for helping us to perform this work. We wish especially to thank Mrs. Irma Immonen, Mag. Agr. and For., who carried out the rumen microbial determinations.

\section{REFERENCES}

AвоU AккаdA, A. R. 1965. The metabolism of ciliate protozoa in relation to rumen function. Physiology of digestion in the ruminant, 335-345. Ed. Dougherty, R. W. Washington.

Asplund, J. M. 1975. The determination and significance of biological values of proteins for ruminants. Protein nutritional quality of foods and feeds 1:37-49. Ed. Friedman, M. New York.

BARnett, A. J. G. and REID, R. L. 1961. Reactions in the rumen. 252 p. London.

BARRY, T. N. 1976. The effectiveness of formaldehyde treatment in protecting dietary protein from rumen microbial degradation. Proc. Nutr. Soc. 35: 221-229.

Chalmers, M. I. Cuthbertson, D. P. and Synge, R. L. M. 1954. Ruminal ammonia formation in relation to the protein requirement of sheep. I. Duodenal administration and heat processing as factors influencing fate of casein supplements . J. Agric. Sci. 44: 254-262.

-, and SYNGE R. L. M. 1954. Ruminal ammonia formation in relation to the protein requirement of sheep. II. Comparison of casein and herringmeal supplements. J. Agric. Sci. 44: 263-269.

Chalupa, W. 1975. Rumen bypass and protection of proteins and amino acids. J. Dairy Sci. 58: $1198-1218$.

Cotryn, B. G. and Boucoue, C. V. 1968. Rapid method for the gaschromatographic determination of volatile fatty acids in rumen fluid. J. Agr. Food Chem. 16:105-107.

FAIChNey, G. J. and Weston, R. H. 1971. Digestion by ruminant lambs of a diet containing formaldehyde-treated casein. Austr. J. Agric. Res. 22: 460-468.

Ferguson, K. A. 1975. The protection of dietary proteins and amino acids against microbial fermentation in the rumen. Digestion and metabolism in the ruminant $448-464$. Ed. McDonald, I. W. and Warner, A. C. I. Sydney.

Glimp, H. A. Karr,M. R. Little, C. O. Woolfolk, P. G. Mitchell, G. E. Jr. and Hudson, L. W. 1967. Effect of reducing soybean protein solubility by dry heat on the protein utilization of young lambs. J. Anim. Sci. 26: 858-861.

HAgemeister, H. 1977. Effect of protein protection on the supply of protein to ruminants. 2nd Intern. Symposium on protein metab. and nutr. Flovohof.

Hudson, L. W. Glimp, H. A., Litrle, C. O. and Woolfolk, P. G. 1970. Ruminal and postruminal nitrogen utilization by lambs fed heated soybean meal. J. Anim. Sci. 30: 609613.

Hume, L. D. 1974. The proportion of dietary protein escaping degradation in the rumen of sheep fed on various protein concentrates. Austr. J. Agric. Res. 25: 155-165.

Hungate, R. E. 1966. The rumen and its microbes. 533 p. New York.

Litrle, C. O., Burroughs, W. and Woods, W. 1963. Nutritional significance of soluble nitrogen in dietary proteins for ruminants. J. Anim. Sci. 22: 358-363.

McCullough, H. 1967. The determination of ammonia in whole blood by a direct colorimetric method. Clin. Chim. Acta 17: 297-304. 
McDonald, I. W. 1948. The absorption of ammonia from the rumen of the sheep. Biochem. J. 42: 584-587.

- 1952. The role of ammonia in ruminal digestion of protein. Biochem. J. 51: 86-90. OXFord, A. E. 1964. A guide to rumen microbiology. Bulletin 160, 103 p. New Zealand.

Rauen, H. M. 1964. Biochemisches Taschenbuch II. 1084 p. Berlin.

Schumacher, E. 1962. Uber die Wirkung einiger Sulfonamide und Antibiotika auf die Infusorien und die Gärgasbildungen im Panseninhalt des Rindes. Schweiz. Arch. Tierheilk. 104: 491-518.

Sherrod, L. B. and Trllman, A. D. 1962. Effects of varying the processing temperature upon the nutritive values for sheep of solventextracted soybean and cottonseed meals. J. Anim. Sci. 21: $901-910$.

SYRJÄLÄ, L. 1972. Effect of different sucrose, starch and cellulose supplements on the utilization of grass silages by ruminants. Ann. Agric. Fenn. 11: 199-276.

-, 1977. Effect of carbohydrate supplements on the utilization of silage protein. Landbrukshögskolan, Inst. för husdj. utfodring och vård. Uppsala, Raport. 54: 55-66.

-, , Kossil.A, V. and SipILÄ, H. 1973. A study of nutritional status of Finnish reindeer (Rangifer Tarandus L.) in different months. I. Composition and volume of the rumen microbiota. J. Scient. Agric. Soc. Finl. 45: 534-541.

-, , Poutiainen, E. \& Koskela, V.-H. 1978. Untreated and formaldehyde treated skimmilk powder as a protein supplement for dairy cows. J. Scient. Agric. Soc. Finl. 50: $155-165$.

-, , Saloniemi, H. and Laalahti, L. 1976. Composition and volume of the rumen microbiota of sheep fed on grass silage with different sucrose, starch and cellulose supplements. J. Scient. Agric. Soc. Finl. 48: 138-153.

Syvãoja, E.-L. and KreUlA, M. 1978. The effect of processing treatments on the rumen microbial digestion in vitro of skimmilk powder protein. J. Scient. Agric. Soc. Finl. 50: $147-154$.

WARNER, A. C. I. 1962. Some factors influencing the rumen microbial population. J. gen.

-, Microbiol. 28: 129-146.

1965. Factors influencing numbers and kinds of micro-organisms in the rumen. Physiology of digestion in the ruminant. p. 346-359. Ed. Daugherty, R. W., Washington.

Ms received March 13, 1978

\section{SELOSTUS}

\section{Käsittelemättömän, formaldehydillä käsitellyn ja ohran kanssa pelletoidun maitojauheen hyväksikäyttö märehtijöillä}

Lissa Syrjälä $\ddot{A}^{1}$ ), Eeva-Lirsa Syvãoja ${ }^{2}$ ) ja Marjatta Boman ${ }^{1}$ )

1) Helsingin yliopiston Kotieläintieteen laitos, 00710 Helsinki 71

2) Biokemiallinen tutkimuslaitos, Kalevankatu 56 B, 00180 Helsinki 18

Maitovalkuaisen hyväksikäyttöä märehtijällä tutkittiin kolmella eri tavoin käsitellyllä sumutuskuivatulla rasvattomalla maitojauheella:

1) Käsittelemätön maitojauhe

2) Formaldehydillä käsitelty maitojauhe $(0.4 \mathrm{~g}$ formaldehydiä/100 $\mathrm{g}$ raakavalkuaista)

3) Pelletoitu maitojauhe (30\% maitojauhetta ja $70 \%$ ohrajauhoa)

Koe suoritettiin pötsifistelillä varustetulla kolmella lypsylehmällä $3 \times 3$ latinalaisen neliön mukaan. Jokaisen koejakson pituus oli kaksi viikkoa. Perusrehuina olivat heinä, säilörehu ja propionihapolla säilötty ohra ja kaura sekä kivennäis- ja vitamiinirehut. Ruokinta oli ravinnontarpeen mukainen. Jokaisessa dieetissẩ korvattiin $25 \%$ maidontuotantoon tarvittavasta valkuaisesta maitovalkuaisella. 
Eri käsittelyjen vaikutusta maitovalkuaisen hyväksikäyttöön selvitettiin pötsineste-, verija maitonäytteiden perusteella. Pötsistä otettiin jokaisen koejakson kahtena viimeisenä päivänä kuusi näytettä (ennen ruokintaa eli klo 04.45 ja ruokinnan jälkeen klo 06, 07, 08, 11 ja 13), joista määritettiin $\mathrm{pH}$, ammoniakki, haihtuvat rasvahapot sekä pötsimikrobien määrä ja laatu.

Pelleteissä olevan maitovalkuaisen hajoaminen pötsissä oli hitaampaa kuin formaldehydillä käsitellyn ja käsittelemättőmän maitovalkuaisen. Tätä osoittaa se, että pötsinesteen ammoniakkipitoisuus oli alhaisin pellettidieetillä. Myōs formaldehydilla käsiteltyä maitojauhetta sisältävällä dieetillä se oli jonkin verran alhaisempi kuin käsittelemätöntä maitojauhetta sisältävällä dieetillä. Erot olivat tilastollisesti merkitseviä kuitenkin vain pellettidieetin ja käsittelemätöntä maitojauhetta sisältävän dieetin välillä. Pötsinesteen $\mathrm{pH}$-arvot olivat korkeammat pellettidieetillä kuin muilla dieeteillä. Ne pysyivät kuitenkin kaikilla dieeteillä normaaliarvojen rajoissa. Pötsinesteen haihtuvien rasvahappojen määrissä ei ollut merkitseviä eroja eri dieeteillä.

Pötsin alkueläinten mäårä oli suurin kåsittelemätôntä maitojauhetta sisältãvällä dieetillä ja pienin pellettidieetillä. Bakteereita sensijaan oli vähiten edellisellä dieetillä. Bakteereiden osuus mikrobiston kokonaismassasta vaihteli eri dieeteillä $72-88 \%$ pienimmän luvun ollessa käsittelemätőntä maitovalkuaista sisältävällä dieetillä ja suurimman pellettidieetillä. Koko mikrobimassan prosenttinen osuus pötsin sisällön tilavuudesta oli eri dieeteillä seuraava: käsittelemätön maitojauhedieetti $3.3 \%$, formaldehydillä käsitelty $3.2 \%$ ja pellettidieetti $2.9 \%$

Maitomäärissä sekä veriarvoissa ei ollut eroja eri dieettien välillä. Maidon valkuaisprosentti sensijaan oli merkitsevästi korkeampi käsittelemätöntä maitovalkuaista sisältävällä dieetillä kuin pellettidieetillä. 